\title{
EFFECT OF HOT WATER TREATMENT WITH CALCIUM DIPS ON POSTHARVEST QUALITY OF TOMATO
}

\author{
WONG JING HAO, IFFAH HAZIRAH MOHD NAWI* and NOR IDZWANA MOHD IDRIS \\ Faculty of Fisheries and Food Science, Department of Crop Science, \\ Universiti Malaysia Terengganu, 21030 Kuala Nerus, Terengganu \\ ${ }^{*}$ E-mail: iffahhazirah@umt.edu.my
}

Accepted 13 October 2020, Published online 25 December 2020

\begin{abstract}
Tomato is fruit vegetables sustaining valuable benefits in economy and nutrition. It has a high content of Vitamin $\mathrm{C}$ and lycopene. Being a climacteric fruit, tomato is perishable and has a short shelf life. To improve the storage quality of tomato, the effect of hot water treatment and calcium dips on tomato (Solanum lycopersicum) was studied. Tomato fruits were dipped in two temperatures $\left(40^{\circ} \mathrm{C}\right.$ and $\left.50^{\circ} \mathrm{C}\right)$ of the hot water bath for 2 minutes before treatment of $2 \%$ calcium chloride for 2 minutes. The fruits were stored at $10^{\circ} \mathrm{C} \pm 2{ }^{\circ} \mathrm{C}$ in the cold room at a relative humidity of $80-95 \%$. Changes in weight loss, firmness, total soluble solids (TSS), titratable acidity, ascorbic acid, and lycopene content were observed and recorded on 0 , $2,4,6,8,10,12,14$ days of storage. Hot water treatment at $50^{\circ} \mathrm{C}$ with $2 \%$ of calcium chloride can control the weight loss and firmness of tomato with the low level of total soluble solids and acidity and retained the level of ascorbic acid. This treatment prone to extend shelf life, delay ripening and retained the postharvest quality of tomato.
\end{abstract}

Key words: Calcium chloride, hot water treatment, tomato, postharvest treatment

\section{INTRODUCTION}

Tomato (Solanum lycopersicum L. or Lycopersicon esculentum) belongs to the nightshade family, Solanaceae. It is one of the most important and widely cultivated vegetables in the world for its fleshy fruits (Kapsiya et al., 2015). Tomato is a good source of potassium, Vitamin C, folic acid, carotenoids, and lycopene (Arab \& Steck, 2000). It is a climacteric fruit with a short life span, usually 2 to 3 weeks (Gharezi et al., 2012). Thus, harvesting on a specific stage and with the proper postharvest treatment of the fruit can maintain the postharvest quality of tomato. The United State Department of Agriculture (USDA) (1991) established six ripening stages of tomato which are green with $100 \%$ green; breaker, a noticeable break in color with lesser than $10 \%$ of other than green color; turning, between 10 and $30 \%$ of the surface, in the aggregate, of red(ish) color; pink, between 30 and $60 \%$ of red(ish) color; light red, between 60 and $90 \%$ and red, more than $90 \%$ red. However, the selected stage to harvest the tomato fruits is depending on the purposes.

* To whom correspondence should be addressed.
According to Shankara et al. (2005), the high water content of tomatoes makes them vulnerable to postharvest losses. Overmature fruit was easily damaged or rotted. The deep red fruits have shorter market life and are more susceptible to bruising during harvest and postharvest handling. Tomato fruit also continues to ripen by emitting ethylene and increased the rate of respiration. High respiration rate thus will lead to the breakdown of tissues and thus fasten the ripening and senescence processes. These resulted in postharvest loss and shorten the shelflife. Postharvest losses can be defined as measurable quantity and quality loss of crops at harvest, storage, transportation, processing, marketing and preparation (Kiaya, 2014). The losses can be occurred because of reduction in shelf life, quality deterioration, microbial infection, diseases, improper packaging and storage condition.

To overcome the loss, application of postharvest treatment such as hot water treatment, edible coating, and chemical treatments with proper storage conditions and packaging are needed. Postharvest treatments are intended to slow down the ripening process and senescence changes, minimize the microbial growth, delaying the respiration rate and thus extend the storage and marketable life of fruits. 
Hot water treatment is potential in controlling infection, maintaining the fruit quality, reducing chilling injury, and improving the shelf life (Lurie \& Pedreschi, 2014). Heat can be applied to fruits and vegetables, including melon and tomato, as hot water dips (HWD), vapour heat, or hot dry air. Moreover, hot water treatment is inexpensive and easily applied at commercial scale, particularly in treatments of short duration (Hofman et al., 2002). Prestorage heat treatments to control decay are often applied for a relatively short time (minutes) because the target pathogens are found on the surface or in the first few cell layers under the skin of the fruit or vegetable (Fallik, 2004). Meanwhile, the addition of calcium chloride dipping is widely used as preservatives and firming agent to maintain the firmness of the fruits. Calcium is an essential plant nutrient since the divalent $\mathrm{Ca}^{2+}$ is required for structural roles in the cell wall and membranes, as a counter-cation for inorganic and organic anions in the vacuole and as an intracellular messenger in the cytosol (Fallahi et al., 1997). The treatment such as calcium chloride dipping can increase the shelf life and maintaining the quality of peach fruit (Sohail et al., 2015). Meanwhile, calcium application combined or not with heat treatments had maintained firmness in a wide variety of fruit and vegetables including lettuce and cantaloupe (Roura et al., 2008). This study evaluated the effect of hot water and calcium chloride treatment to postharvest quality of tomato.

\section{MATERIALS AND METHODS}

\section{Sample preparation}

Tomato fruits (variety Holand) were freshly harvested and bought from Tomato Farm, Cameron Highland with maturity index 3 . They were washed with sodium hypochloride and let to dry before treatment. They were treated with hot water treatment at $40^{\circ} \mathrm{C}$ or $50^{\circ} \mathrm{C}$ for 2 minutes with or without dipping in $2 \%$ of $\mathrm{CaCl}_{2}$ for 2 minutes. For control, the fruits were stored at $10^{\circ} \mathrm{C}$ without any treatment. The fruits were stored in the basket inside the chiller with a temperature of $10^{\circ} \mathrm{C}$ for 14 days with 4 replicates. The relative humidity inside the chiller was set at $80-95 \%$. The analysis was conducted every 2 days interval.

\section{Weight loss and firmness analysis}

The fresh weight of tomato fruits was measured every 2 days until 14 days of storage. The differences in weight loss were expressed as a cumulated percentage of weight loss from the initial weight. The firmness of tomato was measured using TA.XT plus texture analyser (Stable Macro
Systems Ltd.). The maximum force-exerted (expressed as g-force) was used for firmness data.

\section{Ascorbic acid analysis}

Ascorbic acid was measured by titrating $1 \mathrm{~mL}$ of tomato juice and $25 \mathrm{~mL}$ of oxalic acid with 2,6dichlorophenolindophenol (DCPIP) solution until light rose pink colour persists. The ascorbic acid content was calculated as:

$\begin{aligned} & \text { Concentration } \\ & \text { of ascorbic acid }\end{aligned}=\frac{\begin{array}{c}\text { DCPIP (mL) used to } \\ \text { titrate tomato juice }\end{array}}{\begin{array}{c}\text { DCPIP }(\mathrm{mL}) \text { used to } \\ \text { titrate standard }\end{array}} \times 1 \mathrm{mg} / \mathrm{mL}$

\section{Lycopene analysis}

$1 \mathrm{~g}$ of homogenized tomato was mixed with 20 $\mathrm{mL}$ of acetone: ethanol: hexane $(1: 1: 2)$. The mixture was stirred for 15 minutes. Then, $3 \mathrm{~mL}$ of water was added and the sample was shaken on ice. The sample was left at room temperature for 5 minutes. The upper layer was transferred to a cuvette and its absorbance was read at $503 \mathrm{~nm}$ (Fish et al., 2002). The lycopene content was calculated using the following formula:

Lycopene content $(\boldsymbol{\mu g} / \mathrm{g})=\left(\mathrm{A}_{503} \times \mathrm{V} \times 10^{6}\right) /(\varepsilon \times$ $100 \times \mathrm{m})$

Molar extinction coeeficient $(\varepsilon)=17.2 \times 10^{4} / \mathrm{M} / \mathrm{cm}$ $\mathrm{V}=$ total volume of extract $\mathrm{m}=$ sample weight $(\mathrm{g})$

\section{Total soluble solids (TSS) and titratable acidity (TA) analysis}

Total soluble solids (TSS) were determined using a refractometer and expressed as ${ }^{\circ}$ Brix. Titratable acidity (TA) was obtained by titrating 10 $\mathrm{mL}$ of juice sample with $0.1 \mathrm{~N} \mathrm{NaOH}$ up to $\mathrm{pH} 8.2$. The method is described as in AOAC (AOAC, 2005). The result expressed as a percentage of citric acid using the following equation:

$$
\% \text { citric acid } / \text { malic acid }=\frac{\begin{array}{c}
\text { Titre } \times \text { normality of alkali } \times \\
\text { volume made up } \times \\
\text { equivalent weight } \times 100
\end{array}}{\begin{array}{c}
\text { Volume take for estimation } \times \\
\text { weight of sample } \times 100
\end{array}}
$$

\section{Statistical analysis}

One way ANOVA repeated measures, and nonparametric tests Kruskal Wallis were carried out. The level of significance used is $(p<0.05)$. The data were subjected to IBM SPSS Statistic 20 software (Java). 


\section{RESULTS AND DISCUSSION}

\section{Physical characteristics of tomato}

There was a significant increase in weight loss within 14 days of treatment (Figure 1). Tomato treated at $40^{\circ} \mathrm{C}$ of hot water in combination with $2 \%$ of $\mathrm{CaCl}_{2}$ (T2) showed the lowest weight loss with $3.1 \mathrm{~g}$ compared to the treatment with hot water alone and control. Meanwhile, treatment at $50{ }^{\circ} \mathrm{C}$ with $2 \%$ of $\mathrm{CaCl}_{2}$ (T4) showed the second-lowest of weight loss and insignificantly difference with treatment $\mathrm{T} 2$. Weight loss occurs in all treatments throughout the storage period due to the transpiration and respiration of fruits. Temperature manipulation is one of the effective methods that can affect the respiration rate and thus controlling weight loss. Safdar (2009) indicated that hot water treatment reduces fresh weight loss of tomato over control at the end of 25 days of storage. However, the addition of $\mathrm{CaCl}_{2}$ can improve the postharvest treatment of tomato in controlling the weight loss. Calcium plays a role in maintaining the membrane permeability and integrity and thus restrict water transfer and delaying dehydration (Sohail et al., 2015). The effectiveness of hot water treatment and dipping in calcium chloride in controlling the weight loss was observed in papaya study (Ayón-Reyna et al., 2017).

Firmness indicates the texture of tomato that changed during ripening. It is one of the important indicators of fruit quality. The softening occurred because of the degradation of biopolymers in the cell wall (Prasanna et al., 2007). Tomato treated in hot water at $50^{\circ} \mathrm{C}$ in combination with $2 \%$ of $\mathrm{CaCl}_{2}$ for 2 minutes (T4) showed the highest firmness level compared to control (Figure 2). Although, no significant difference on firmness level was observed between all treatments. Naser et al. (2018) observed that persimmon treated with hot water at $45^{\circ} \mathrm{C}$ and $50^{\circ} \mathrm{C}$ had better in controlling the firmness. This might be that hot water treatment can reduce cell wall degrading enzymes and thus can maintain cell strength. Thus resulted in delaying of the ripening process (Pan et al., 2004). Meanwhile, a study by Senevirathna and Daundasekera (2010) indicated that fruits treated with $\mathrm{CaCl}_{2}$ exhibited firmer texture. Calcium gives an extra benefit in controlling the firmness as it determines the cell structure and integrity (Poovaiah et al., 1988).

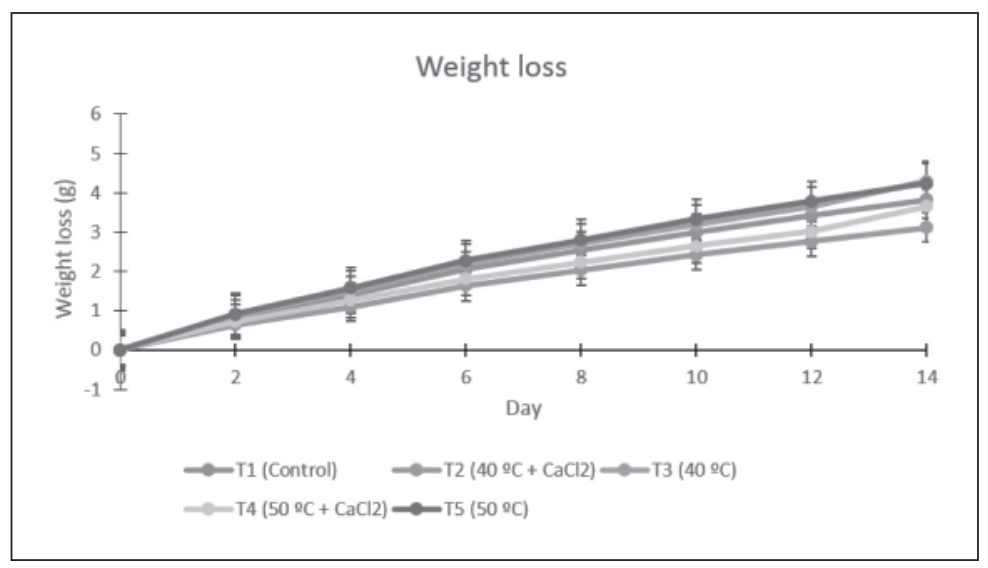

Fig. 1. Weight loss of tomato during 14 days of storage.

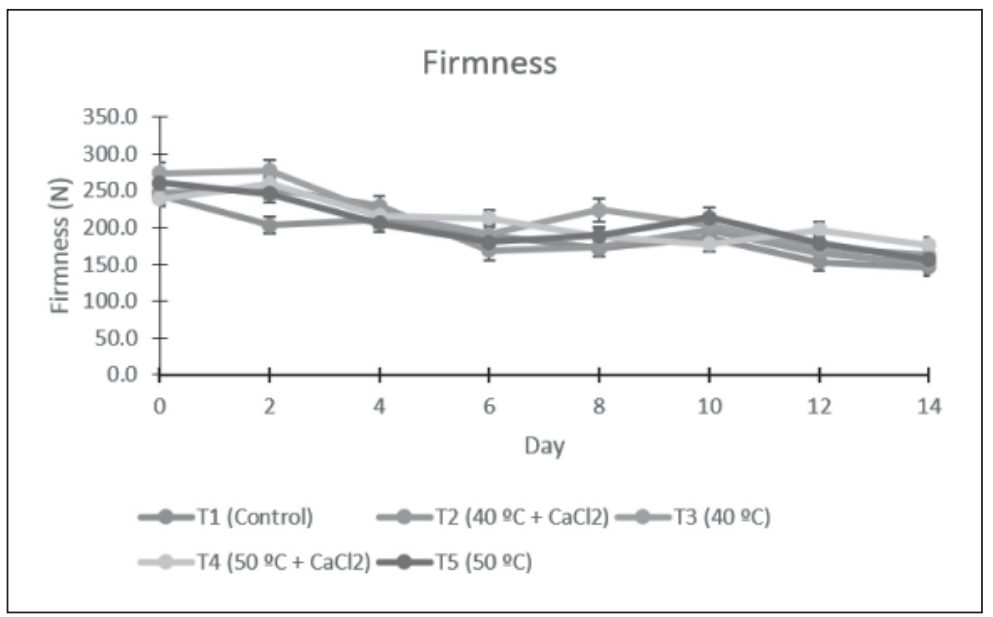

Fig. 2. Firmness of tomato during 14 days of storage. 


\section{Biochemical analysis of tomato}

\section{Ascorbic acid}

Ascorbic acid is one of the important antioxidants in the diet (Mahdavi et al., 2010). Its concentration decreased upon ripening and also can be affected by the high temperature which leads to degradation. The result (Figure 3) showed that control (T1) and treatment with the combination of hot water treatment and calcium chloride dipping (T2 and T4) can reduce the loss of ascorbic acid compared to the hot water treatment alone (T5). There was a significant difference in the concentration of ascorbic acid among the treatments on day 2,6 , and 8 . On day 4 , the ascorbic acid content was increased and reached a peak. This might be because the tomato fruit reached the maturity stage (Sinaga, 1986). Meanwhile, the reduction in ascorbic acid content is due to the degradation by heat and oxidation.

\section{Lycopene}

Lycopene is the pigment that contributes to deep red colour of ripe tomato fruits and mostly located in tomato skin. It is an antioxidant which is sensitive to excessive heat, $\mathrm{pH}$ value, and overlight exposure (Shi \& Le Maguer, 2000). There are no significant differences in lycopene content between treated and untreated tomato fruits (Figure 4). During 14 days of storage, all of the treated tomato fruits and control showed an elevated of lycopene content that indicates the ripening process. The degradation of chlorophyll and increased lycopene content results in the formation of red colour during ripening processes (Yadaz, 2009). Although, tomato treated with $40^{\circ} \mathrm{C}$ of hot water treatment (T3) showed the highest lycopene content compared to the control. Previously, hot water treatment before storage enhances the synthesis of lycopene in the green and pink stage of tomatoes (Kalantari et al., 2014). Meanwhile, control fruit can reduce the

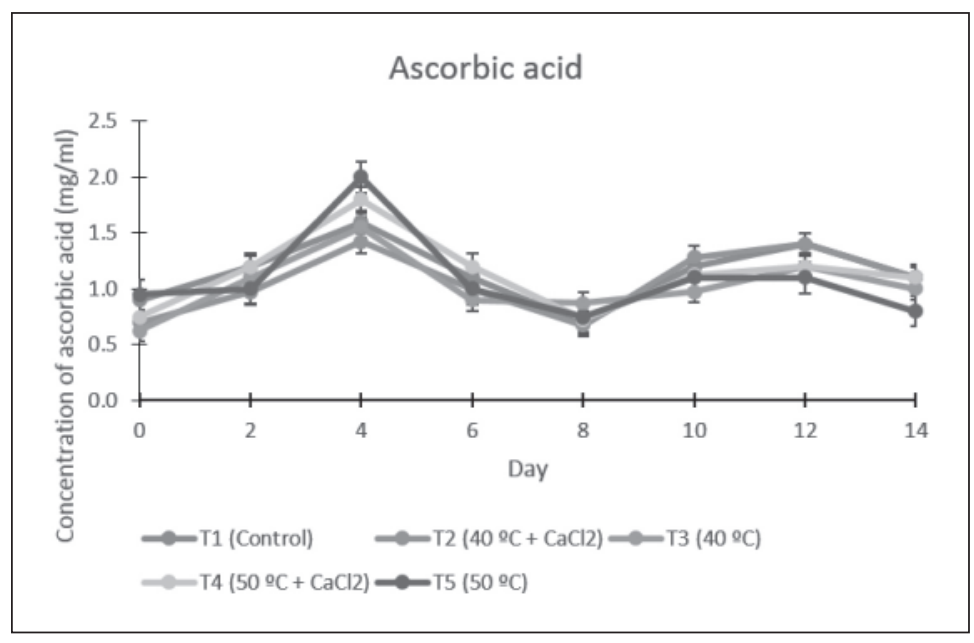

Fig. 3. Concentration of ascorbic acid during 14 days of storage.

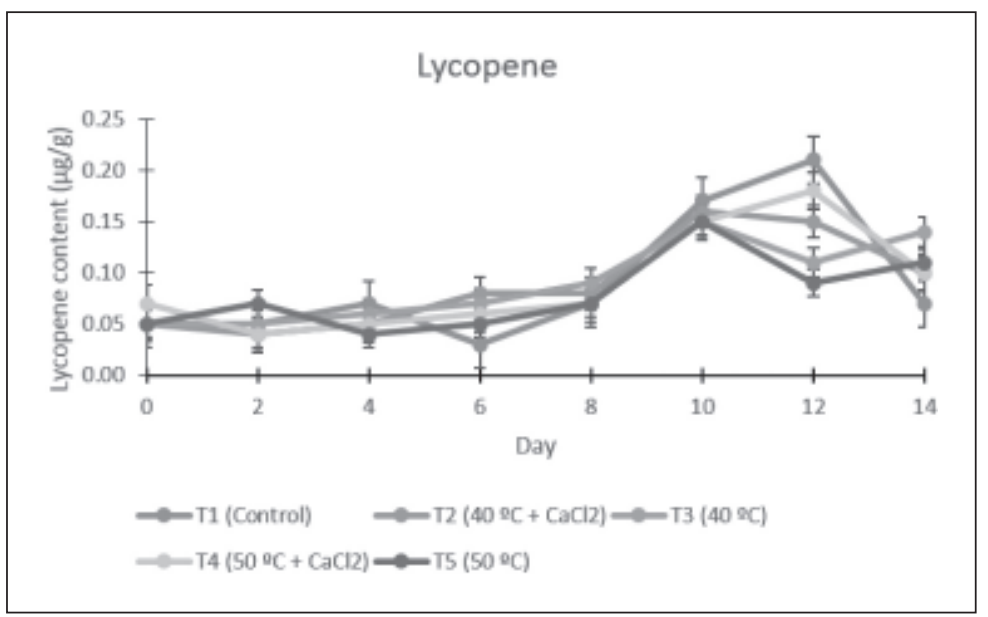

Fig. 4. Lycopene content in tomato. 
accumulation of lycopene because of the cold storage that induces chilling stress (Tadesse \& Abtew, 2016).

\section{Total soluble solids}

The tomato fruit sweetness is a factor that affected the flavouring of tomato fruit. This sweetness has resulted from the presence of glucose and fructose (Stevens \& Kader, 1977). In this present study, the total soluble solids (TSS) value of tomato fruits in all samples and control showed slightly increased as the ripening goes on within 14 days of storage (Figure 5). Meanwhile, there was a significant difference between the treatment of $50^{\circ} \mathrm{C}$ alone (T5) and control on day 12 . The increase in TSS is due to the hydrolysis of starch into simple sugar and degradation of the cell wall during ripening (Hussain et al., 2008). At the end of 14 days of storage, control had the highest TSS value (4.1\%) compared to the other treatments. High TSS value indicates high respiration rate and metabolic activity and thus increase the ripening processes.

\section{Titratable acid}

Acidity is important in determining the maturity of the fruit. There was a significant difference among the treatments with the control on day 2, 4, 6, and 12 (Figure 6). Meanwhile, all of the treatments and control showed a reduction of titratable acid after 14 days of storage. A declined of acidity in tomato during the storage is resulted from the consumption of organic acid for metabolism activity including respiration (Bhatnagar et al., 2006).

\section{CONCLUSION}

Hot water treatment with calcium dipping can reduce postharvest loss by the retained postharvest quality of tomatoes and prolong the shelf life.

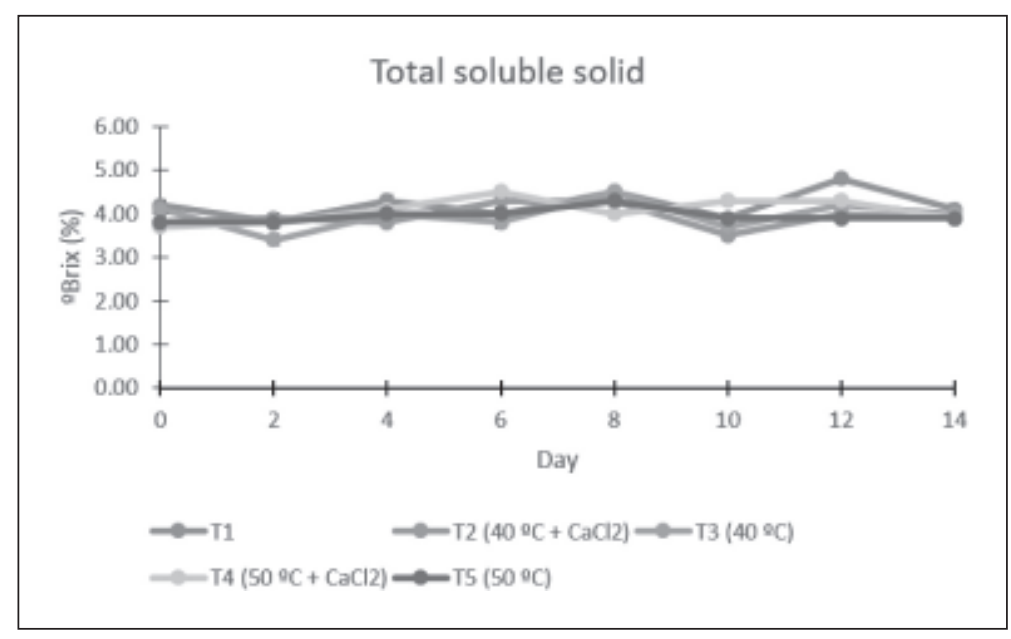

Fig. 5. Total soluble solid in tomato.

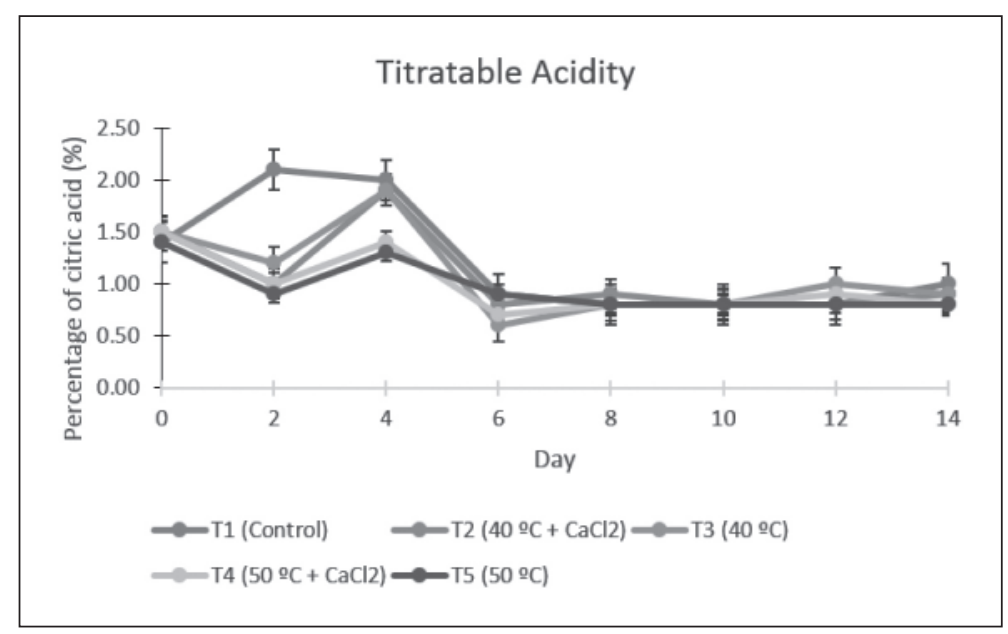

Fig. 6. Titratable acidity in tomato. 
Calcium chloride helps in controlling the ripening process and reduces respiration. Since tomato fruits are highly perishable and prone to rapid loss after harvest, thus it is important to apply post-harvest treatment to maintain their quality and delay the ripening process. Thus, hot water treatment and calcium dips are potential as postharvest treatment and can be applied in the tomato industry to improve the shelf life of tomato and maintain its quality.

\section{ACKNOWLEDGMENT}

This work was financially supported by the Universiti Malaysia Terengganu.

\section{REFERENCES}

AOAC. 2005. Official Method of Analysis. 18th Ed. Association of Officiating Analytical Chemists, Arlington, Virginia.

Arab, L. \& Steck, S. 2000. Lycopene and cardiovascular disease. American Journal of Clinical Nutrition, 71: 1691-1695.

Ayón-Reyna, L.E., López-Valenzuela, J.A., DelgadoVargas, F., López-López, M.E., Molina-Corral, F.J., Carrillo-López, A. \& Vega-Garcia, M.O. 2017. Effect of the combination hot watercalcium chloride on the in vitro growth of Colletotrichum gloeosporioides and the postharvest quality of infected papaya. Plant Pathology Journal, 33(6): 572-581.

Bhatnagar, D.K., Singh, G.P., Singh, J.P. \& Singh, B.P. 2006. Studies on the storage behaviour of different tomato cultivars. Haryana Agricultural University Journal of Research, 10: 59.

Fallahi, E., Conway, W.S., Hickey, K.D. \& Sams, C.E. 1997. The role of $\mathrm{Ca}$ and nitrogen in postharvest quality and disease resistance of apples. HortScience, 32: 831-835.

Fallik, E. 2004. Prestorage hot water treatments (immersion, rinsing and brushing). Postharvest Biology and Technology, 32: 125-134.

Fish, W.W., Perkins-Veazie, P. \& Collins, J.K. 2002. A quantitative assay for lycopene that utilizes reduced volumes of organic solvents. Journal of Food Composition and Analysis, 15: 309317.

Gharezi, M., Joshi, N. \& Sadeghian, E. 2012. Effect of post harvest treatment on stored cherry tomatoes. Journal of Nutrition and Food Science, 2: 157-167.

Hofman, P.J., Stubbings, B.A., Adkins, M.F., Meiburg, G.F. \& Woolf, A.B. 2002. Hot water treatments improve 'Hass' avocado fruit quality after cold disinfestation. Postharvest Biology and Technology, 24: 183-192.

Hussain, P.R., Dar, M.A., Meena, R.S., Mir, M.A., Shaf, F. \& Wani, A.M. 2008. Changes in quality of apple (Malus domestica) cultivars due to gamma irradiation and storage conditions. Journal of Food Science and Technology, 45: 444-449.

Kalantari, S., Hatami, M. \& Delshad, M. 2014. Diverse postharvest responses of tomato fruits at different maturity stages to hot water treatment. International Journal of Horticultural Science and Technology, 2(1): 67-74.

Kapsiya, J., Gungula, D.T., Tame, V.T. \& Bukar, N. 2015. Effects of storage chemicals and packaging systems on physicochemical characteristics of tomato (Solanum lycopersicum L.) Fruits. AASCIT Journal of Bioscience, 1: 41-46.

Kiaya, V. 2014. Postharvest losses and strategies to reduce them. Technical paper on Post-Harvest Losses, Action Contre la Faim (ACF International), New York.

Lurie, S. \& Pedreschi, R. 2014. Fundamental aspects of postharvest heat treatments. Horticulture Research, 30: 1-7.

Mahdavi, R., Nikniaz, Z., Rafraf, M. \& Jouyban, A. 2010. Determination and comparison of total polyphenol and vitamin $\mathrm{C}$ contents of natural fresh and commercial fruit juices. Pakistan Journal of Nutrition, 9: 968-972.

Naser, F., Rabiei, V., Razavi, F. \& Khademi, O. 2018. Effect of calcium lactate in combination with hot water treatment on the nutritional quality of persimmon fruit during cold storage. Scientia Horticulturae, 233: 114-123.

Pan, J., Vicente, A.R., Martinez, G.A., Chaves, A.R. \& Civello, P.M. 2004. Combined use of UV-C irridiation and heat treatment to improve postharvest life of strawberry fruit. Journal of the Science of Food and Agriculture, 84: 18311838.

Poovaiah, B.W., Glenn, G.M. \& Reddy, A. 1988. Calcium and fruit softening: physiology and biochemistry. Horticulture Review, 10: 107152.

Prasanna, V., Prabha, T.N. \& Tharanathan, R.N. 2007. Fruit ripening phenomena - An overview. Critical Reviews in Food Science and Nutrition, 47: 1-9.

Roura, S., Pereyra, L. \& Del Valle, C. 2008. Phenylalanine ammonia lyase activity in fresh cut lettuce subjected to the combined action of heat mild shocks and chemical additives. Food Science and Technology, 41: 919-924.

Safdar, K.M. 2009. Effect of Post-harvest Hot Water and Hot Air Treatments on Quality and Shelf Life of Tomato. University of Reading, United Kingdom. 
Senevirathna, P.A.W.A.N.K. \& Daundasekera, W.A.M. 2010. Effect of postharvest calcium chloride vacuum infiltration on shelf life and quality of tomato (cv. Thilina). Ceylon Journal of Biological Science, 39: 35- 44.

Shi, J. \& Le Maguer, M. 2000. Lycopene in tomatoes: chemical and physical properties affected by food processing. Critical Reviews in Food Science and Nutrition, 40: 1-42.

Sinaga, R.M. 1986. Effect of maturity stages on quality if tomato cv. Money maker. Bulletin Penelitian Hoticulture, 13(2): 43-53.

Sohail, M., Ayub, M., Khalil, S.A., Zeb, A., Ullah, F., Afridi, S.R. \& Ullah, R. 2015. Effect of calcium chloride treatment on postharvest quality of peach fruit during cold storage. International Food Research Journal, 22: 2225-2229.

Stevens, M.A., Kader, A., Albright-Holten, M.A. \& Algazi, M. 1977. Effect of fruit ripeness when picked on flavor and composition in fresh market tomatoes. Journal of the American Society for Horticultural Science, 102: 724-731.
Tadesse, T.N. \& Abtew, W.G. 2016. Effect of hot water treatment on reduction of chilling injury and keeping quality in tomato (Solanum lycopersicum L.) fruits. Academic Journal, 7(7): 61-68.

USDA. 1991. Standard for Grades of Fresh Tomatoes. United States Department of Agriculture.

Wills, R.B.H., McGlasson, W.B., Grahmam, D., Lee, T.H. \& Hall, E.G. 2004. Postharvest - An Introduction to the Physiology and Handling of Fruits and Vegetables. Granada Publishing Ltd, London.

Yadav, R.K., Sanwal, S.K., Singh, P.K. \& Juri, B. 2009. Effect of pretreatments and packaging of tomato in LDPE and PET films on the storagelife. Journal of Food Science and Technology, 46: 139-141. 
